\title{
The impact of ECB and FED announcements on the Euro interest rates
}

\author{
Andrea Monticini ${ }^{\mathrm{a}, *}$, David Peel ${ }^{\mathrm{b}}$, Giacomo Vaciago ${ }^{\mathrm{a}}$ \\ ${ }^{\text {a }}$ Catholic University, Milan, Italy \\ ${ }^{\mathrm{b}}$ University of Lancaster, United Kingdom
}

\section{A R T I C L E I N F O}

\section{Article history:}

Received 29 May 2010

Received in revised form

20 May 2011

Accepted 24 May 2011

Available online 6 June 2011

\section{JEL classification:}

E40

E52

\section{Keywords:}

Monetary policy shocks

Identification

Wild bootstrap

\begin{abstract}
A B S T R A C T
We investigate the impact of news in the ECB and FED monetary policy announcements on daily changes in Euro interest rates. We document significant impacts of ECB announcements throughout the period but only until mid 2004 of FED announcements.
\end{abstract}

(C) 2011 Elsevier B.V. All rights reserved.

\section{Introduction}

An issue which has been investigated by a number of authors is the reactions of market interest rates in country $i$ to the monetary policy decisions of the Central Bank in country $i$ as well as to the decisions of the Central Banks of other countries ${ }^{1}$ (see e.g. Kuttner (2001), Thornton (2009), Ehrmann and Fratzscher (2005) and Valente (2009)). Following a suggestion of Rudebusch (1998) and the empirical work of Kuttner (2001) it has become a standard approach to employ the futures rate to decompose monetary policy announcements into their expected and surprise components (see Hamilton (2008), Piazzesi and Swanson (2008), Poole et al. (2002) and Thornton (2009)).

\footnotetext{
We thank Aurora, Raffaella and an anonymous referee for helpful comments. All remaining errors are ours.

* Corresponding address: Catholic University of Milan - Largo Gemelli No. 1, 20123 Milano, Italy. Tel.: +3902 72343215; fax: +3902 72342781.

E-mail address: andrea.monticini@unicatt.it (A. Monticini).

1 An important channel by which monetary policy announcements by the Central Bank of country, $i$, can cause changes in market interest rates of country, $j$, include superior information about output or inflation in country, $i$, with potential implications for output, inflation and hence interest rates in country $j$. For example Romer and Romer (2000) report the important finding that the Federal Reserve appears to possess information about the future state of the economy that is not known to market participants. They estimate that commercial forecasters would find it nearly optimal to discard their forecasts and adopt the Federal Reserves for both real output as well as for inflation.

See Belke and Gros (2005) and Ehrmann and Fratzscher (2005) for other channels.
}

However in an important contribution, Thornton (2009) shows that estimating the relationship between interest rates and the futures rate measure of news only for days of Central Bank announcements, as is typically the case in empirical analysis, leads to bias in estimates of the news impact. His point is that interest rates and market-based measures of monetary policy news respond simultaneously to all news and not just news in the monetary policy announcements. Consequently, it is necessary to estimate relationships between the futures measure of news and market determined interest rates for every day and not only for days when there are monetary announcements. Employing the methodology of Thornton using daily data over the period from 1st January 1999 to 30th August 2006, we investigate the impact of news in the ECB and FED monetary policy announcements on daily changes in Euro interest rates. We document significant impacts of ECB announcements throughout the period but only until mid 2004 of FED announcements. The latter result on the news content of FED announcements is consistent with the analysis of Thornton (2009) who reports an insignificant impact of FED announcements on changes in US interest rates over a sample period that has significant overlap with the one employed in this letter.

\section{Future prices and news}

Rudebusch (1998) suggests that the federal funds futures rate is a natural forecast of the Federal Open Market Committee target for the federal funds rate, and Kuttner (2001) used the federal funds futures rate to decompose target changes into their 
Table 1

FED and ECB number of meetings and decisions in basis points (bp).

\begin{tabular}{lcc}
\hline & FED & ECB \\
\hline & No. of meetings & No. of meetings \\
\hline Maintained & 28 & 108 \\
$+50 \mathrm{bp}$ & 1 & 2 \\
$+25 \mathrm{bp}$ & 22 & 9 \\
$-25 \mathrm{bp}$ & 4 & 3 \\
$-50 \mathrm{bp}$ & 6 & 5 \\
Tot. of meetings & 61 & 127 \\
\hline
\end{tabular}

expected and surprise components. Since then, it has become a standard approach to measure the response of interest rates to unanticipated monetary policy actions through market-based measures of unanticipated monetary policy action (Hamilton, 2008; Piazzesi and Swanson, 2008; Poole et al., 2002, see). The idea is to compute the difference between two appropriate future prices: this difference should capture the news generated by the monetary policy announcement, under the assumption of market efficiency.

In general, we can interpret the future price at time $t-1\left(f_{t-1}\right)$ as the conditional expectation (conditioned with respect to the information set $I)^{2}$ of the spot rate $(r)$ at the maturity date $(m)$.

$E\left[r_{m} \mid I_{t-1}\right]=f_{m, t-1}$.

Then, the news generated by the monetary policy announcements $(N)$ will be given by the change in the conditional expectation:

$N_{t}=E\left[r_{m} \mid I_{t}\right]-E\left[r_{m} \mid I_{t-1}\right]=f_{m, t}-f_{m, t-1}$.

It is important to observe (as outlined by Thornton (2009)) the market-based measures of monetary policy news $(N)$ respond to all news, and not only news about monetary policy actions.

Having defined a measure of monetary policy shocks we have all the ingredients to study the impact of both the ECB and the FED monetary policy announcements on the Euro rates.

\section{Empirical analysis}

The analysis covers the period from 1st January 1999 to 30th August 2006: we prefer to avoid more recent observations to prevent contamination of the results by the recent turmoil in financial markets. ${ }^{3}$

In the period analysed, the ECB had a greater number of meetings than the FED (see Table 1 for details). ${ }^{4}$

In order to estimate the impact of the FED announcements on the Euro rates, we estimate by OLS regression

$$
\begin{aligned}
\Delta R_{t}^{\text {Euro }}= & \alpha_{0}+\alpha_{1} \text { TC }+\alpha_{2} \text { TC } 1+\beta_{1} T C * N_{t} \\
& +\beta_{2} \text { TC } 1 * N_{t+1}+\beta_{3} \Delta R_{t-1}^{\text {Euro }}+\beta_{4} N_{t}+\varepsilon_{t}
\end{aligned}
$$

where $\Delta R_{t}^{\text {Euro }}$ is the change in the seven Euro rates we consider, $N_{t}=f_{m, t}-f_{m, t-1}$ is the futures measure of news. ${ }^{5} \mathrm{TC}$ is a 1,0 dummy variable which is equal to one on days of ECB announcements and zero otherwise. TC 1 is a 1, 0 dummy variable

\footnotetext{
2 Technically, the information set $I$ is a $\sigma$-field.

3 Our dataset comes from DATASTREAM, the total number of observations are 1995.

4 The ECB had two meetings per month before November 2001. In November 2001 the ECB Governing Council announced that, as a rule, it would assess its monetary policy stance only in the first meeting of the month. For this reason, we have considered only the first meeting of the month since November 2001.

5 We use the future contract on Euribor three month: this contract is traded on the Eurex Exchange.
}

which is equal to one on days of FED monetary announcements ${ }^{6}$ and zero otherwise ${ }^{7}$. We note the regression includes, our measure of news, $N$, on all days in order to avoid the possible bias in estimates of ECB and FED news as well as an intercept shift on the announcement days as set out by Thornton (2009). The error term is $\varepsilon_{t} \sim$ i.i.d. $\left(0, \sigma_{t}^{2}\right)$ with possibly $\sigma_{t}^{2} \neq \sigma_{s}^{2}$ for $t \neq s$.

\section{Discussion}

The empirical results are reported in Tables 2-4. Due to the significant non-normality in the residuals, but the absence of significant serial correlation, the standard errors for the OLS point estimates are obtained by employing the wild bootstrap, a heteroscedasticity consistent covariance matrix (HC) which is recommended by Gonçalves and Kilian (2004). ${ }^{8}$

The whole period results show that both the ECB and FED announcements have significantly different impacts than other news on interest rates on horizons up to 10 years with the ECB announcements having a greater impact. Thornton (2009) finds "...no FED shocks larger than 2 basis points in absolute value starting from 30 June 2004" (see Thornton, 2009, p. 19). It is important to remember that starting in May 2004 the FOMC adopted the "measured pace" language in its statement. This fact was regarded as indicating that the FOMC would increase its funds rate target by 25 basis points at its next meeting. This expectation was fulfilled by the FOMC at each of the next 14 meetings. More generally, the "measured pace" language ${ }^{9}$ increased the predictability of FED's decisions.

Has the adoption of the "measured pace" language by the FOMC changed the impact of FED announcements on the Euro rates as well? To answer this question, we look at this subperiod splitting of our sample. The first subsample runs from 1999:01:01 to 2004:06:30, while the second subsample runs from 2004:06:30 to 2006:08:30. We find that though the ECB news announcements remain significant in both periods this is not the case for FED announcements or all news in the latter periods. ${ }^{10}$ Our results suggest that Euro interest rates were essentially driven by ECB announcements in the latter half of the period examined. It is interesting to note that Thornton (2009) found no significant response of US treasury rates at any maturity to FED monetary announcements employing a futures measure of news over the period $2000-2007$. He notes that the lack of a statistically significant response over this period does not appear to be solely due to the greater predictability of funds rate target changes; rather, it might reflect a fundamental change in the relationship between the federal funds rate and other interest rates. Thornton (2007, p.1) investigates this issue. He hypothesizes that the marked change in the relationship occurred because the Federal Open

\footnotetext{
6 For the FED shocks, we ought to consider $N$ at $t+1$ because FED announcement is delivered at 18:15 GMT and the future price on the three month Euribor has a daily settlement calculated at 18:00 GMT (except on the last trading day when it is at 10:00 GMT). $N_{t}$ contains the ECB shocks but it does not contain the FED shocks. On the contrary, the Euro rates $R^{\text {Euro }}$ employed in this study are fixed at 10:00 GMT. $R_{t-1}^{\text {Euro }}$ does not contain either ECB or FED announcement.

7 Results for anticipated policy changes are always insignificant and are available on request.

8 Results based on standard HC are almost always identical to those provided in Tables 2-4 and available upon request. To save space we have not reported the tests for autocorrelation in the residuals. However, for all the estimated models we cannot reject the null hypothesis of no-autocorrelation up to lag 8 at $1 \%$ level applying both the Ljung-Box and Box-Pierce tests.

We employ the $1,-1$ with $p=0.5$ (Rademacher distribution) form of the wild bootstrap.

9 See Thornton (2006) for a discussion of the "measured pace" language.

10 The Chow test rejects the null of no structural break (30 June 2004) at the $1 \%$ level for all the rates examined.
} 
Table 2

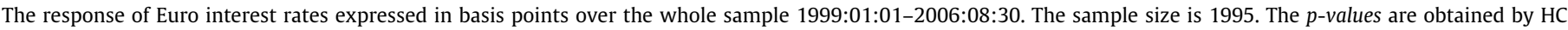
covariance and 399 wild bootstrap replications.

\begin{tabular}{|c|c|c|c|c|c|c|c|c|c|c|}
\hline & $\alpha_{0}$ & $\alpha_{1}$ & $\alpha_{2}$ & $\beta_{1}$ & $\beta_{2}$ & $\beta_{3}$ & $\beta_{4}$ & LM ARCH & N. Res. & $\bar{R}_{a d j}^{2}$ \\
\hline $1 \mathrm{~m}$ & $\begin{array}{l}0.00 \\
(0.65)\end{array}$ & $\begin{array}{c}-0.10 \\
(0.82)\end{array}$ & $\begin{array}{c}-0.40 \\
(0.15)\end{array}$ & $\begin{array}{l}73.30^{* * * *} \\
(0)\end{array}$ & $\begin{array}{c}24.91^{* * * *} \\
(0)\end{array}$ & ${ }_{(0)}^{12.04^{* * * *}}$ & $\begin{array}{l}3.09 \\
(0.013)\end{array}$ & $\begin{array}{l}0.31 \\
(0.57)\end{array}$ & $251_{(0)}^{104^{* * *}}$ & 0.185 \\
\hline $1 \mathrm{y}$ & $\begin{array}{l}0.00 \\
(0.24)\end{array}$ & $\begin{array}{c}-0.42 \\
(0.22)\end{array}$ & $\begin{array}{c}-0.00 \\
(0.92)\end{array}$ & $\underset{(0)}{82.12^{* * * *}}$ & ${ }_{(0)}^{42.11^{* * * *}}$ & $\begin{array}{c}5.36^{* * * *} \\
(0)\end{array}$ & $\begin{array}{l}14.69^{* * * *} \\
(0)\end{array}$ & $\begin{array}{l}0.52 \\
(0.47)\end{array}$ & $\begin{array}{c}950^{* * * *} \\
(0)\end{array}$ & 0.19 \\
\hline $2 y$ & $\begin{array}{c}-0.10 \\
(0.30)\end{array}$ & $\begin{array}{l}0.36 \\
(0.47)\end{array}$ & $\begin{array}{c}0.1 \\
(0.83)\end{array}$ & ${ }_{(0)}^{81.67^{* * * *}}$ & $\begin{array}{l}51^{* * * *} \\
(0)\end{array}$ & $\begin{array}{l}-5.95^{* * *} \\
(0.011)\end{array}$ & ${ }^{30.99^{* * * *}}$ & $\begin{array}{l}1.67 \\
(0.19)\end{array}$ & $\underset{(0)}{185.73^{* * * *}}$ & 0.115 \\
\hline $5 y$ & $\begin{array}{c}-0.13 \\
(0.38)\end{array}$ & $\begin{array}{l}0.31 \\
(0.56)\end{array}$ & $\begin{array}{l}0.00 \\
(0.99)\end{array}$ & $\underset{(0)}{59.1}$ & $\underset{(0)}{35.12^{* * * *}}$ & $\begin{array}{c}-6.79^{*} \\
(0.07)\end{array}$ & $\begin{array}{l}37.14^{* * * *} \\
(0)\end{array}$ & $\begin{array}{l}1.83 \\
(0.17)\end{array}$ & $\begin{array}{c}1512^{* * * *} \\
(0)\end{array}$ & 0.055 \\
\hline $10 y$ & $\begin{array}{c}-0.17 \\
(0.45)\end{array}$ & $\begin{array}{l}-0.0 \\
(0.94)\end{array}$ & $\begin{array}{c}-0.00 \\
(0.9)\end{array}$ & $\begin{array}{c}35.47^{* * * *} \\
(0)\end{array}$ & $\underset{(0.16)}{25.61}$ & $\begin{array}{c}-4.97 \\
(0.31)\end{array}$ & $\begin{array}{l}30.74^{* * * * *} \\
(0)\end{array}$ & $\begin{array}{l}1.29 \\
(0.25)\end{array}$ & $\begin{array}{c}4423^{* * * *} \\
(0)\end{array}$ & 0.016 \\
\hline $20 y$ & $\begin{array}{l}-0.0 \\
(0.79)\end{array}$ & $\begin{array}{c}-0.48 \\
(0.47)\end{array}$ & $\begin{array}{c}0.2 \\
(0.77)\end{array}$ & $\begin{array}{l}8.19 \\
(0.28)\end{array}$ & $\begin{array}{c}7 \\
(0.79)\end{array}$ & $\begin{array}{c}-13.79^{* * *} \\
(0.02)\end{array}$ & $\underbrace{24.63^{* * * *}}_{(0.01)}$ & $\begin{array}{l}1.86 \\
(0.17)\end{array}$ & $\underset{(0)}{4311.45^{* * *}}$ & 0.02 \\
\hline $30 y$ & $\begin{array}{c}-0.25 \\
(0.59)\end{array}$ & $\begin{array}{c}-0.84 \\
(0.2)\end{array}$ & $\begin{array}{l}0.14 \\
(0.82)\end{array}$ & $\underset{(0.22)}{11.14}$ & $\begin{array}{l}0.52 \\
(0.98)\end{array}$ & $\begin{array}{c}-5.59 \\
(0.37)\end{array}$ & $\begin{array}{c}34.07^{* * * *} \\
(0)\end{array}$ & $\begin{array}{c}2.5 \\
(0.12)\end{array}$ & $\underset{(0)}{4854.2^{* * *}}$ & 0.004 \\
\hline
\end{tabular}

** Denote $10 \%$ significance level respectively ( $p$-values shown in parenthesis).

** Denote $5 \%$ significance level respectively ( $p$-values shown in parenthesis).

*** Denote $1 \%$ significance level respectively ( $p$-values shown in parenthesis).

Table 3


and 399 wild bootstrap replications.

\begin{tabular}{|c|c|c|c|c|c|c|c|c|c|c|}
\hline & $\alpha_{0}$ & $\alpha_{1}$ & $\alpha_{2}$ & $\beta_{1}$ & $\beta_{2}$ & $\beta_{3}$ & $\beta_{4}$ & LM ARCH & N. Res. & $\bar{R}_{a d j}^{2}$ \\
\hline $1 \mathrm{~m}$ & $\begin{array}{c}-0.00 \\
(0.54)\end{array}$ & $\begin{array}{c}-0.14 \\
(0.79)\end{array}$ & $\begin{array}{l}-0.5 \\
(0.14)\end{array}$ & $\begin{array}{c}71.6^{* * * *} \\
(0)\end{array}$ & $\begin{array}{l}25.75^{* *} \\
(0.02)\end{array}$ & $\underset{(0)}{11.82^{* * * *}}$ & $\begin{array}{l}3.95^{* *} \\
(0.03)\end{array}$ & $\begin{array}{l}0.13 \\
(0.71)\end{array}$ & $\underset{(0)}{14477.4^{* * * *}}$ & 0.17 \\
\hline $1 \mathrm{y}$ & $\begin{array}{c}-0.00 \\
(0.41)\end{array}$ & $\begin{array}{l}0.59 \\
(0.14)\end{array}$ & $\begin{array}{c}-0.23 \\
(0.55)\end{array}$ & $\begin{array}{c}78.7^{* * * *} \\
(0)\end{array}$ & $\underset{(0)}{41.96^{* * *}}$ & $\begin{array}{l}4.88 \\
(0.11)\end{array}$ & ${ }_{(0)}^{16.57^{* * * *}}$ & $\begin{array}{l}0.33 \\
(0.56)\end{array}$ & $513.95^{* * * *}$ & 0.192 \\
\hline $2 y$ & $\begin{array}{l}-0.0 \\
(0.8)\end{array}$ & $\begin{array}{l}0.55 \\
(0.34)\end{array}$ & $\begin{array}{c}-0.27 \\
(0.61)\end{array}$ & $\underset{(0)}{78.69^{* * * *}}$ & $\begin{array}{c}54.29^{* * * *} \\
(0)\end{array}$ & $\begin{array}{l}-2.89 \\
(0.27)\end{array}$ & $\begin{array}{l}32.29^{* * * *} \\
(0)\end{array}$ & $\begin{array}{l}0.73 \\
(0.39)\end{array}$ & $\underset{(0)}{138.1^{* * * *}}$ & 0.134 \\
\hline $5 y$ & $\begin{array}{l}0.00 \\
(0.76)\end{array}$ & $\begin{array}{l}0.00 \\
(0.95)\end{array}$ & $\begin{array}{l}0.00 \\
(0.95)\end{array}$ & ${ }_{(0)}^{57.66^{* * * *}}$ & ${ }_{(0)}^{46.51^{* * * *}}$ & $\begin{array}{c}-1.29 \\
(0.61)\end{array}$ & $27.00^{* * * *}$ & $\begin{array}{l}1.89 \\
(0.16)\end{array}$ & $\begin{array}{c}83.7^{* * * *} \\
(0)\end{array}$ & 0.078 \\
\hline $10 y$ & $\begin{array}{l}0.00 \\
(0.51)\end{array}$ & $\begin{array}{c}-0.36 \\
(0.47)\end{array}$ & $\begin{array}{c}-0.11 \\
(0.83)\end{array}$ & $\begin{array}{c}33.4^{* * * *} \\
(0)\end{array}$ & $\begin{array}{c}38.86^{* * *} \\
(0)\end{array}$ & $\begin{array}{l}-0.7 \\
(0.78)\end{array}$ & ${ }_{(0)}^{1.69^{* * * *}}$ & $\begin{array}{l}0.06 \\
(0.8)\end{array}$ & $\begin{array}{c}69.55^{* * * *} \\
(0)\end{array}$ & 0.04 \\
\hline $20 y$ & $\begin{array}{l}0.00 \\
(0.46)\end{array}$ & $\begin{array}{l}-1.1 \\
(0.12)\end{array}$ & $\begin{array}{c}0.3 \\
(0.68)\end{array}$ & $\begin{array}{l}10.1^{*} \\
(0.07)\end{array}$ & $\begin{array}{c}17.58 \\
(0.51)\end{array}$ & $-\underset{(0)}{9.53^{* * * *}}$ & $\begin{array}{c}14.57^{* * * *} \\
(0)\end{array}$ & $\begin{array}{l}0.52 \\
(0.46)\end{array}$ & $\underset{(0)}{189.81^{* * *}}$ & 0.024 \\
\hline $30 y$ & $\begin{array}{l}0.12 \\
(0.27)\end{array}$ & $\begin{array}{l}-1.43 \\
(0.12)\end{array}$ & $\begin{array}{c}-0.00 \\
(0.83)\end{array}$ & $\begin{array}{c}11.85 \\
(0.2)\end{array}$ & $\begin{array}{c}22.99 \\
(0.13)\end{array}$ & $\begin{array}{l}3.04 \\
(0.28)\end{array}$ & $\begin{array}{c}12.47^{* * * *} \\
(0)\end{array}$ & $\begin{array}{l}1.77 \\
(0.18)\end{array}$ & $\begin{array}{c}413.18^{* * * *} \\
(0)\end{array}$ & 0.023 \\
\hline
\end{tabular}

" Denote $10 \%$ significance level respectively ( $p$-values shown in parenthesis).

** Denote $5 \%$ significance level respectively ( $p$-values shown in parenthesis).

*** Denote $1 \%$ significance level respectively ( $p$-values shown in parenthesis).

Table 4

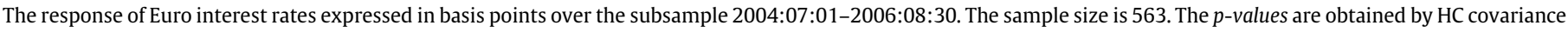
and 399 wild bootstrap replications.

\begin{tabular}{|c|c|c|c|c|c|c|c|c|c|c|}
\hline & $\alpha_{0}$ & $\alpha_{1}$ & $\alpha_{2}$ & $\beta_{1}$ & $\beta_{2}$ & $\beta_{3}$ & $\beta_{4}$ & LM ARCH & N. Res. & $\bar{R}_{a d j}^{2}$ \\
\hline $1 \mathrm{~m}$ & $\begin{array}{l}0.16 \\
(0.108)\end{array}$ & $\begin{array}{c}0.103 \\
(0.88)\end{array}$ & $\begin{array}{l}0.00 \\
(0.55)\end{array}$ & $\begin{array}{c}84.48^{* * * *} \\
(0)\end{array}$ & $\begin{array}{l}2.47 \\
(0.62)\end{array}$ & $\begin{array}{l}10.2^{* *} \\
(0.012)\end{array}$ & $\begin{array}{c}-3.48 \\
(0.48)\end{array}$ & $\underset{(0.94)}{0.004}$ & $\underset{(0)}{336.05^{* * * *}}$ & 0.41 \\
\hline $1 \mathrm{y}$ & $\begin{array}{l}0.2 \\
(0.11)\end{array}$ & $\begin{array}{c}-0.21 \\
(0.71)\end{array}$ & $\begin{array}{l}1.06 \\
(0.125)\end{array}$ & $\underset{(0)}{107.1^{* * * *}}$ & $\begin{array}{c}49.89 \\
(0.12)\end{array}$ & $\begin{array}{l}6.34 \\
(0.33)\end{array}$ & $\begin{array}{c}0.6 \\
(0.33)\end{array}$ & $\begin{array}{l}0.9 \\
(0.34)\end{array}$ & $\begin{array}{c}176.37^{* * * *} \\
(0)\end{array}$ & 0.21 \\
\hline $2 y$ & $\begin{array}{c}-0.32 \\
(0.11)\end{array}$ & $\begin{array}{c}-0.57 \\
(0.62)\end{array}$ & $\begin{array}{l}1.3 \\
(0.2)\end{array}$ & $\underset{(0)}{98.51^{* * * *}}$ & $\begin{array}{c}-29.67 \\
(0.74)\end{array}$ & $-\underset{(0)}{15.03^{* * *}}$ & $\begin{array}{c}20.71 \\
(0.17)\end{array}$ & $\begin{array}{l}1.34 \\
(0.24)\end{array}$ & ${ }_{(0)}^{29.53^{* * * *}}$ & 0.065 \\
\hline $5 y$ & $\begin{array}{c}-0.52 \\
(0.22)\end{array}$ & $\begin{array}{l}0.89 \\
(0.44)\end{array}$ & $\begin{array}{c}-0.79 \\
(0.68)\end{array}$ & $\begin{array}{c}70.44 * * * \\
(0)\end{array}$ & $\begin{array}{c}-92.29 \\
(0.37)\end{array}$ & $\begin{array}{c}-11.83^{*} \\
(0.07)\end{array}$ & $\underset{(0.13)}{117.84}$ & $\begin{array}{l}1.88 \\
(0.17)\end{array}$ & $\underset{(0)}{245.93^{* * * *}}$ & 0.072 \\
\hline $10 \mathrm{y}$ & $\begin{array}{c}-0.66 \\
(0.35)\end{array}$ & $\begin{array}{c}0.55 \\
(0.7)\end{array}$ & $\begin{array}{c}-0.49 \\
(0.8)\end{array}$ & $\begin{array}{l}60^{* * * *} \\
(0)\end{array}$ & $\begin{array}{c}-76.58 \\
(0.36)\end{array}$ & $\begin{array}{c}-5.41 \\
(0.35)\end{array}$ & $\underset{(0.22)}{139.27}$ & $\begin{array}{l}0.1 \\
(0.75)\end{array}$ & $\underset{(0)}{296.04^{* * * *}}$ & 0.028 \\
\hline $20 y$ & $\begin{array}{c}-0.45 \\
(0.67)\end{array}$ & $\begin{array}{l}1.56 \\
(0.56)\end{array}$ & $\begin{array}{c}-0.97 \\
(0.62)\end{array}$ & $\begin{array}{c}-4.13 \\
(0.94)\end{array}$ & $\begin{array}{c}-96.74 \\
(0.57)\end{array}$ & $\begin{array}{c}-14.46^{* *} \\
(0.02)\end{array}$ & $\begin{array}{c}-129.3 \\
(0.53)\end{array}$ & $\begin{array}{l}0.97 \\
(0.62)\end{array}$ & $\underset{(0)}{226.85^{* * * *}}$ & 0.018 \\
\hline $30 y$ & $\begin{array}{c}-0.98 \\
(0.52)\end{array}$ & $\begin{array}{l}0.48 \\
(0.82)\end{array}$ & $\begin{array}{c}0.5 \\
(0.81)\end{array}$ & $\begin{array}{c}21.76 \\
(0.73)\end{array}$ & $\begin{array}{c}-149.7 \\
(0.3)\end{array}$ & $\begin{array}{c}-5.43 \\
(0.41)\end{array}$ & $\begin{array}{l}207 \\
(0.23)\end{array}$ & $\begin{array}{c}2.022 \\
(0.15)\end{array}$ & $\underset{(0)}{275.6^{* * * *}}$ & 0.009 \\
\hline
\end{tabular}

"Denote $10 \%$ significance level respectively ( $p$-values shown in parenthesis).

** Denote $5 \%$ significance level respectively ( $p$-values shown in parenthesis).

*** Denote $1 \%$ significance level respectively ( $p$-values shown in parenthesis).

Market Committee (FOMC) switched from using the funds rate as an operating instrument (i.e. main guide for conducting the open market operations) to using it as a policy target (i.e. a target set to achieve specific policy objectives). He hypothesizes that the change is due to an instance of Goodhart's Law: "any observed statistical regularity will tend to collapse once pressure is placed upon it for control purpose". Our results appear consistent with Thornton (2009) and Thornton (2007), at least for the latter period (he did not consider the early sub-period). In fact, considering the great integration of financial markets internationally, we can explain our results using similar arguments to those provided by Thornton (2007). It would appear that FED announcements had no significant impact on either US or Euro interest rates in the period mid 2004-mid 2006. On the other hand ECB announcements appear to have a significant news impact on interest rate changes up to a 10-year horizon over the whole period considered.

Finally, it is interesting to note the smaller response of longterm interest rates and neither announcement has an effect on the 30 -year bond rates in all the periods considered (this fact is also true for the 20-year bond rates with one exception). Both facts are not new. Kuttner (2001) notes that changes in the overnight rate affect longer term rates only to the extent that they lead to revisions in expectations of future overnight rates; the more persistent are the changes, the larger the effect on expectation, and mean reversion in the overnight rate set by a central bank implies smaller responses for bonds farther out the yield curve. 
Moreover, monetary policy news can change real rates, inflation expectations and inflation risk premia: the effects can cancel out, leaving zero impact on the nominal rate. Beechey and Wright (2009) provide empirical evidence supporting this rationalization and further discussion of the economic implications.

\section{References}

Beechey, M.J., Wright, J.H., 2009. The high-frequency impact of news on long-term yields and forward rates: is it real? Journal of Monetary Economics 56, 535-544.

Belke, A., Gros, D., 2005. Asymmetries in trans-atlantic monetary policy making: does the ECB follow the FED? CESifo Working Paper, no. 1428.

Ehrmann, M., Fratzscher, M., 2005. Equal size, equal role? Interest rate interdependence between the Euro area and the United States. Economic Journal 115, 928-948.

Gonçalves, S., Kilian, L., 2004. Bootstrapping autoregressions with conditional heteroskedasticity of unknown form. Journal of Econometrics 123, 89-120.

Hamilton, J.D., 2008. Assessing monetary policy effects using daily federal funds futures contracts. Federal Reserve Bank of St. Louis Review 90 (4), 377-393.
Kuttner, K.N., 2001. Monetary policy surprise and interest rates: evidence from the fed funds futures market. Journal of Monetary Economics 47 (3), 523-544.

Piazzesi, M., Swanson, E.T., 2008. Futures prices and risk-adjusted forecasts of monetary policy. Journal of Monetary Economics 55 (4), 677-691.

Poole, W., Rasche, R.H., Thornton, D.L., 2002. Market anticipations of monetary policy actions. Federal Reserve Bank of St. Louis Review 84 (4), 65-94.

Romer, C., Romer, D., 2000. Federal reserve information and the behaviour of interest rates. American Economic Review 90, 429-457.

Rudebusch, G.D., 1998. Do measures of monetary policy in a var make sense? International Economic Review 39, 907-931.

Thornton, D.L., 2006. Measured pace in the conduct of monetary policy. Federal Reserve Bank of St. Louis, Monetary Trends.

Thornton, D.L., 2007. The unusual behavior of the federal funds rate and treasury yields: a conundrum or an instance of Goodhart's law? Federal Reserve Bank of St. Louis Working Paper, 2007-039D.

Thornton, D.L., 2009. The identification of the response of interest rates to monetary policy actions using market-based measures of monetary policy shocks. Federal Reserve Bank of St. Louis Working Paper, 2009-037A.

Valente, G., 2009. International interest rates and US monetary policy announcements: evidence from Hong Kong and Singapore. Journal of International Money and Finance 28 (6), 920-940. 